\title{
Modernising higher education: the emergence of European public goods
}

\author{
Peter van der Hijden
}

\begin{abstract}
Universities cater mainly for national audiences. But the days of splendid isolation are over. Students, graduates, faculty and staff vote with their feet. Institutions and system are, increasingly, involved in processes of regionalisation and globalisation. This article describes how a number of European initiatives are transforming the way universities operate in education, research and management. Incentives for change range from earmarked funding to projects grants and loans, from voluntary networking and benchmarking to quality audits and rankings. These instruments for change have become part of the fabric of university life, often consolidated in institutional strategies and national legislation. They are emerging as 'European public goods'. This article highlights a number of these initiatives in the various categories and points at their impact on university practice.
\end{abstract}

Keywords: European Higher Education Area; Bologna Process; European Research Area; EU Modernisation Agenda for Higher Education; Erasmus+; Horizon 2020; Human Resources Strategies; Doctoral Training.

\section{Introduction}

Universities are teaching, doing research and fostering innovation. They are contributing substantially to the well-being of their region and country, but not only that. Ideas born at universities can resonate throughout the world. Alumni can find places to study and work at home and abroad. From an EU perspective, universities are helping to build the 'Innovation Union' and reach the aims of the 'Europe 2020 strategy for smart, sustainable and inclusive growth' ${ }^{1}$ The new Commission, started 1 November 2014, will develop its own plans, but will, no doubt, build on these overall strategies.

The EU Modernisation agenda for higher education was laid down in a series of Commission Communications, Expert Groups, Council Conclusions and Resolutions in 2005, 2006, 2007, and 2011. ${ }^{2}$ The EU is an important

${ }^{1}$ European Commission, “Europe 2020," http://ec.europa.eu/europe2020/index_en.htm.

2 "Communication from the Commission of 20 April 2005 - Mobilising the brainpower of Europe: enabling universities to make their full contribution to the Lisbon 
source of funding for universities through programmes like Erasmus+ and Horizon 2020, the European Investment Bank (EIB) and the European Structural and Investment Funds (ESIF).

This paper points at a number initiatives taken at European level in order to stimulate universities to modernise the way they operate in education, research, knowledge transfer and governance. Special attention is given to human resources management and doctoral training. Initiatives with the potential to trigger substantial change in the landscape of European higher education or research are considered 'European Public Goods'. ${ }^{3}$

\section{Modernising higher Education - Bologna Process - Erasmus+}

Universities have been challenged to rethink the way they operate by a number of European initiatives. The most well known and influential is the Bologna process; the most comprehensive is the EU Modernisation agenda for higher education.

The Bologna process requires the introduction of three cycles (bachelor, master, doctorate) with distinct durations and characteristics. Bologna is also about quality, transparency (ECTS credits, Diploma Supplement), student-centred learning, employability, competitiveness, mobility, European dimension (double and joint degrees), connecting education and research (notably doctoral training), social dimension (widening access) and international dimension (attractiveness, capacity building, science diplomacy).

Strategy [COM(2005) 0152 final]," http://eur-lex.europa.eu/legal-content/EN/ TXT/?uri=CELEX:52005DC0152. Informal meeting of the European Council at Hampton Court in October 2005 and Council Resolution of 15 November 2005. Expert Group "Creating an Innovative Europe," chaired by Mr Aho, European Commission, January 2006. Conclusions $1777 / 06$ of 24 March 2006 European Council. "Delivering on the modernisation agenda for universities, education, research and innovation [COM (2006) 208 final of 10 May 2006]." Council Resolution on modernising universities for Europe's competitiveness in a global knowledge economy of 23 November 2007. 16096/1/07REV 1 "Supporting growth and jobs - an agenda for the modernisation of Europe's higher education systems [COM(2011) 567 final of 20 September 2011]." Council conclusions on the modernisation of higher education of 28 and 29 November 2011.

${ }^{3}$ Public good in the general sense: "a shorthand signal for shared benefit at a societal level." Kevin Morrell, "Governance and the public good," Public Administration 87, no. 3 (2009): 543, doi: 10.1111/j.1467-9299.2009.01756.x. 
The EU Modernisation agenda for higher education has embraced the Bologna action lines and has put its own emphasis on good governance (balancing autonomy and accountability), appropriate funding (balancing public and private money), widening access (balancing excellence and equity), lifelong learning and educational innovation (Open Educational Resources, including MOOCs). ${ }^{4}$

Countries have defined National Qualifications Frameworks (NQFs), which describe the various levels of education and training, including the three levels of higher education, in terms of 'learning outcomes' or 'competences': what graduates know and can do. These definitions should fit the references laid down in Bologna- and EU Qualifications' Frameworks (EQF). ${ }^{5}$ Academics gathered in the 'Tuning' project have translated these general statements into subject-specific profiles, which can be used for rewriting curricula together with stakeholders. ${ }^{6}$

The Erasmus+ programme (2014-2020) offers many opportunities to engage in activities, which could help to modernise universities and bring their ambitions in line with the Bologna process and the EU Modernisation agenda for higher education. ${ }^{7}$ One new initiative merits special attention: the European student loan guarantee facility.

\section{European student loan guarantee facility}

Erasmus+ Master degree loans will allow students to apply for support for their master's studies abroad. Loans will be offered by participating banks and student loan agencies on favourable conditions to mobile students, including, better than market interest rates and up to two years to allow graduates to get into a job before beginning repayment. The loan scheme will be established in cooperation with the European Investment Bank Group and

${ }^{4}$ Massive Open Online Courses.

5 "Qualifications Frameworks in the EHEA," http://www .ehea.info/article-details. aspx? ArticleId=65; "RECOMMENDATION OF THE EUROPEAN PARLIAMENT AND OF THE COUNCIL of 23 April 2008 on the establishment of the European Qualifications Framework for lifelong learning (Text with EEA relevance) (2008/C 111/01)," http://eur-lex. europa.eu/legal-content/EN/TXT/PDF/?uri=CELEX:32008H0506(01)\&from=EN.

6 "Tuning Educational Structures in Europe [and elsewhere]," http://www.unideusto.org/ tuningeu.

7 European Commission, "ERASMUS +," http://ec.europa.eu/programmes/erasmusplus/index_en.htm. 
will be gradually rolled out across the programme countries over the first few years of the programme. ${ }^{8}$

This new facility will operate at the heart of the Bologna process. Too few universities have interiorised the principal distinction between the bachelor and master programmes, including the option for the student to 'opt out' after the bachelor and go and work or study in another field, at another institution at home or abroad. The question "should I stay or should I go?" is a very existential one, existential for the student, starting a new life, and existential for the university, which may run empty, unless it offers attractive masters to incoming students. Information on study programmes is increasingly available through English language online course catalogues and national and international portals. ${ }^{9}$ Quality of provision is made public through national and international comparisons and rankings, notably the new U-Multirank..$^{10} \mathrm{~A}$ systematic international comparison of higher education learning outcomes at institutional level would provide much needed insights into educational performances, which are currently lacking. ${ }^{11}$

So far only small percentages of students have opted out after the bachelor. In some fields of study, like engineering, law and medicine, they are even actively encouraged to stay. The number of students leaving after the bachelor will, however, steadily increase and this is a silent revolution for the continental European higher education systems. The European student loan guarantee facility will support and accelerate this trend. It will have an impact on actions universities will take in the areas of curriculum development, recruitment, student selection, mentoring, student services, career services etc. On a different scale, the European student loan guarantee facility will be a kind of G.I. Bill of Rights, which provided grants to returning veterans and thus triggered important developments in post war US higher education. ${ }^{12}$

${ }^{8}$ European Commission, "EDUCATION AND TRAINING. Supporting education and training in Europe and beyond," http://ec.europa.eu/education/opportunities/higher-education/ masters-loans_en.htm.

9 Notaby "StudyPortals," http://www .studyportals.eu/.

10 "U-Multirank," http://www.u-portal.org/u-multirank.

${ }^{11}$ See the attempt through the OECD project Assessment of Higher Education Learning Outcomes (AHELO): "Testing student and university performance globally: OECD's AHELO," http://www.oecd.org/edu/skills-beyond-school/testingstudentanduniversityperformancegloballyoecdsahelo.htm.

${ }_{12}$ Michael J. Bennett, When Dreams Came True: The GI Bill and the Making of Modern America (Dulles, VA: Potomac Books Inc., 1999). 


\section{Modernising Research and Innovation - European Research Area (ERA) - Horizon 2020 - EIB and ESIF}

Universities are key players in research and innovation. They train the next generation of researchers and innovators and they help to find solutions for societal challenges such as climate change, healthy ageing and building innovative and inclusive societies. EU policies and programmes provide guidance and incentives. The main EU policy goal for research remains to establish the European Research Area (ERA) "in which researchers, scientific knowledge and technology circulate freely" (art 179 of the EU Treaty). ${ }^{13}$ The ERA reform agenda consists of five big priorities:

- More effective national research systems;

- Optimal transnational co-operation and competition (on common research agendas, grand challenges and infrastructures);

- An open labour market for researchers (open recruitment, access and portability of grants, mobility information, innovative doctoral training, careers and HR strategies in line with Charter \& Code, mobility between industry and academia, recognition, social security, pensions, visas);

- Gender equality and gender mainstreaming in research (encouraging gender diversity to foster science excellence and relevance); and

- Optimal circulation and transfer of scientific knowledge (to guarantee access to and uptake of knowledge by all).

Horizon 2020 (2014-2020) is one of the world's largest framework programmes for research and innovation. ${ }^{14}$ The programme contains a wealth of opportunities for individuals with bright ideas (Marie Sklodowska-Curie Actions, European Research Council/ERC), companies (new SME instrument, access to risk finance, etc.) and transnational teams of researchers (addressing societal challenges together). The Knowledge and Innovation Communities (KIC) of the European Institute for Innovation and Technology (EIT) combine education, research and innovation. The European Investment Bank (EIB) has Innovation and Skills as one of its four priority areas ${ }^{15}$ and guarantees, for example, the funding of the new European student loan guarantee facility.

${ }^{13}$ European Commission, "European Research Area," http://ec.europa.eu/research/era/ eraprogress_en.htm.

${ }_{14}$ European Commission, "HORIZON 2020. The EU Framework Programme for Research and Innovation,” http://ec.europa.eu/programmes/horizon2020/.

15 European Investment Bank, http://www.eib.europa.eu/projects/priorities/innovation/ index.htm. 
The European Structural and Investment Funds (ESIF) were designed to help less developed and transition regions catch up. In the new funding period, 2014-2020, the focus is on education (skills) innovation, research and development. Each country/region has adopted a Smart Specialisation Strategy, signed an Agreement with the European Commission and adopted a Work Programme. ESIF funding can be combined with funding from other EU programmes like, Erasmus+ and Horizon 2020. ESIF is supporting, for example, the upgrading of university campuses ${ }^{16}$ Of particularly importance in the European research landscape is the European Research Council, part of the Horizon 2020 excellence pillar.

\section{European Research Council}

Grants from the European Research Council (ERC) are awarded through open competition to thousands of projects headed by starting and established researchers, irrespective of their origins, who are working or moving to work in Europe. The ERC's mission is to support investigator-driven frontier research across all fields, on the basis of scientific excellence as the sole criterion. The aim is to recognise the best ideas, and confer status and visibility on the best brains in Europe, while also attracting talent from abroad. Being 'investigator-driven', or 'bottom-up', in nature, the ERC approach allows researchers to identify new opportunities and directions in any field of research, rather than being led by priorities set by politicians. This ensures that funds are channelled into new and promising areas of research with a greater degree of flexibility. ${ }^{17}$

ERC grants are portable. Grant holders can move with their grant to another European research location of their choice. The mere existence of a scheme like ERC stimulates universities to rethink the research environment they offer to current and future staff.

\section{Modernising human resources management}

The European Commission has taken several initiatives to improve the career and mobility of researchers laid down in Communications and Council

${ }^{16}$ For inspiration see: http://managingtheuniversitycampus.nl.

${ }^{17}$ European Research Council, "Mission," http://erc.europa.eu/about-erc/mission. 
Recommendations and Conclusions..$^{18}$ Thousands of jobs and fellowships, funded from various public and private sources are made accessible through EURAXESS Jobs. EURAXESS Services centres are spread out across the wider Europe with Links offices in other continents as well. ${ }^{19}$ The Scientific Visa Directive is under review in order to reduce the red tape for incoming third-country nationals wishing to stay in Europe for the purposes of research, studies, pupil exchange, remunerated and unremunerated training, voluntary service and au pairing. ${ }^{20}$ Two initiatives of particular significance are highlighted below, the Human Resources Strategy for Researchers and the Pan- European Pension Fund for Researchers.

\section{Human Resources Strategies for Researchers}

The European Charter for Researchers and the Code of Conduct for the Recruitment of Researchers are sets of principles and requirements, which specify the roles, responsibilities and entitlements of researchers as well as of employers and/or funders of researchers (Charter \& Code).$^{21} 1200$ organisations from 37 countries have endorsed the Charter \& Code. More than 300 universities, research institutes and funders are currently participating in a peer review exercise based on the Charter \& Code. So far, close to 200 'HR Excellence in Research' logos have been awarded to acknowledge their efforts. ${ }^{22}$ The Human Resources Strategy for Researchers consists of five steps:

18 European Commission's Communication "Researchers in the European Research Area: One Profession, Multiple Careers [COM(2003) 436 final of July 2003, Brussels]," http:// ec.europa.eu/research/fp6/mariecurie-actions/pdf/careercommunication_en.pdf . European Commission's Communication "Better careers and more mobility: a European partnership for Researchers" [COM(2008)317 final of 23.5.2008]," http://ec.europa.eu/euraxess/pdf/research_ policies/comm_pdf_com_2008_0317_f_en_communication.pdf. Council Conclusions on Communication "Better careers and more mobility: a European partnership for Researchers," 26 September 2008. Council Conclusions on "A Reinforced European Research Area Partnership for Excellence and Growth,” 11 December 2012, http://ec.europa.eu/euraxess/pdf/ research_policies/era-communication_en.pdf .Council Conclusions of European research area Progress Report 2014, 5 December 2014.

${ }_{19}$ European Commission, "EURAXESS -Researchers in Motion,” http://ec.europa.eu/ euraxess/.

${ }^{20}$ European Commission, http://ec.europa.eu/dgs/home-affairs/e-library/documents/ policies/immigration/study-or- training/docs/students_and_researchers_proposal_ com_2013_15 1_en.pdf.

${ }^{21}$ European Commission, "The Human Resources Strategies for Researchers (HRS4R)," http://ec.europa.eu/euraxess/index.cfm/rights/strategy4Researcher.

${ }^{22}$ European Commission, "The Human Resources Strategies for Researchers (HRS4R)," http://ec.europa.eu/euraxess/index.cfm/rights/strategy4Researcher. 
1. An internal analysis by the participating research institution or funding organisation, involving all key players, to compare policies and practices against the Charter \& Code principles;

2. On the basis of the results of this analysis, the participating institution or organisation develops its own HR strategy for researchers, which should include a concrete action plan. This document is made public;

3. The analysis and action plan are then reviewed and acknowledged by the European Commission. The acknowledgement implies the right to use the 'HR Excellence in Research' logo;

4. Progress in the implementation of the strategy and action plan is subjected to a self-assessment after 2 years; and

5. An external evaluation is carried out at least every 4 years.

The Charter \& Code are gaining momentum. An Expert Group is examining ways to strengthen step 5, external assessment, of the Human Resources Strategy, whereas the new Horizon 2020 Model Grant Agreement states in Art 32 that "The beneficiary must take all measures to implement the principles set out in the Commission Recommendation on the European Charter for Researchers and the Code of Conduct for the Recruitment of Researchers". ${ }^{23}$

\section{A Pan-European Pension Fund for Researchers}

The mobility of researchers is a driver of excellence in research. However, researchers face many difficulties in preserving their supplementary pension benefits when moving between different countries. To overcome this problem, the European Commission is supporting a consortium of employers, through Horizon 2020, in creating a single European pension arrangement (RESAVER) that will offer a defined contribution plan, tailor-made for research organisations and their employees ${ }^{24}$ RESAVER will enable mobile and non-mobile employees, within a growing network of employers, to remain affiliated to the same pension vehicle when moving between different countries and changing jobs. This will make Europe a more attractive place

\footnotetext{
${ }^{23} \mathrm{http} / /$ ec.europa.eu/research/participants/data/ref/h2020/grants_manual/amga/h2020amga_en.pdf

${ }^{24}$ European Commission, "RESAVER - A Pan-European Pension Fund," http://ec. europa.eu/euraxess/index.cfm/rights/resaver.
} 
to do research, both for EU national and incoming talent. It will also encourage more cooperation between existing national pension funds in the interest of a wider range of mobile citizens..$^{25}$

\section{A pivotal role for doctoral training}

Doctoral degree holders are crucial to the knowledge society. Their critical minds and innovative competences are highly valued by employers. Some become professors, researchers or teachers. Most fullfil important positions outside academia. The EU will need at least an estimated one million new research jobs in order to increase the research intensity of our economies and reach the R\&D target of 3\% of GDP spending. ${ }^{26}$ Universities are changing the way they train doctoral candidates. Inspiration is drawn from the Salzburg Principles and Recommendations of EUA ${ }^{27}$ and the related EU Principles for Innovative Doctoral training. ${ }^{28}$ The EU Principles refer to:

\section{Research Excellence;}

2. Attractive Institutional Environment (in line with the Charter and Code);

\section{Interdisciplinary Research Options:}

4. Exposure to industry and other relevant employment sectors;

5. International networking;

6. Transferable skills training; and

7. Quality Assurance.

${ }^{25}$ See for example Barbara Ottawa, "Germany's VBL launches pension tracker platform for researchers," http://www.findyourpension.eu/portals/vblmaps/story_docs/News/IPE_ Interview.pdf.

${ }^{26}$ According to recent estimates, achieving the target of spending 3\% of EU GDP on R\&D by 2020 could create 3.7 million jobs and increase annual GDP by close to EUR 800 billion by 2025 . This estimate does not include the additional need for researchers to replace those leaving their employment for retirement. Commission Communication Europe 2020 Flagship Initiative Innovation Union COM(2010) 546 final of 6 October 2010 and Researchers Report 2014, European Commission DG Research and Innovation.

${ }^{27}$ European University Association (EUA), "Salzburg II Recommendations: European universities' achievements since 2005 in implementing the Salzburg Principles," http://www. eua.be/Libraries/Publications_homepage_list/Salzburg_II_Recommendations.sflb.ashx.

${ }^{28}$ European Commission, "Principles for Innovative Doctoral Training," http://ec.europa. eu/euraxess/pdf/research_policies/Principles_for_Innovative_Doctoral_Training.pdf, endorsed by the EU Council of Ministers in November 2011. 
The Salzburg Principles refer to the following:

i) The core component of doctoral training is the advancement of knowledge through original research;

ii) Embedding in institutional strategies and policies;

iii) The importance of diversity;

iv) Doctoral candidates as early stage researchers;

v) The crucial role of supervision and assessment;

vi) Achieving critical mass;

vii) Duration;

viii) The promotion of innovative structures;

ix) Increasing mobility; and

x) Ensuring appropriate funding.

Doctorates in Europe, brought in line with these two sets of principles, acquire certain characteristics, which can make them attractive, also because European doctorates have relatively short completion times as compared to doctorates in other world regions. Both the EU and Bologna Ministers of Education and Research have expressed their support for these principles. ${ }^{29}$ The EU Ministers have even invited Member States to "link, where relevant and appropriate, national funding for doctoral programmes to the Principles for Innovative Doctoral Training".

Hundreds of thousands of doctoral candidates are supported, directly or indirectly, through EU programmes, which refer to these principles. Erasmus+ supports the mobility of doctoral candidates as third cycle students. Horizon 2020 provides grants for doctoral candidates under the Marie SklodowskaCurie Actions (MSCA). Doctoral candidates also benefit, as team members, from other Horizon 2020 grants (ERC, Societal Challenges). Other programmes for doctoral candidates are set up and funded locally and nationally, often with support of MSCA COFUND and the European Structural and Investment Funds (ESIF).

The aim is to embed doctorates in Europe in a qualitative framework, which, inevitably, will be implemented in many varieties across Europe. Some doctorates will put emphasis on collaboration with industry and other

${ }^{29}$ Council of the European Union, "Council Conclusions on the modernisation of education," http://www.consilium.europa.eu/uedocs/cms_Data/docs/pressdata/en/ educ/126375.pdf. "Making the Most of Our Potential: Consolidating the European Higher Education Area Bucharest Communiqué. FINAL VERSION," http://www.ehea.info/ Uploads/\%281\%29/Bucharest\%20Communique\%202012\%281\%29.pdf. 
employment sectors. Other doctorates will put an emphasis on cross border cooperation of universities, sometimes being called "European doctorates". Some doctorates will put an emphasis on interdisciplinary research. They are all encouraged to offer research excellence, an attractive institutional environment and internal quality assurance as core elements. ${ }^{30}$

Universities in Europe have taken up this challenge and are reforming their doctoral programmes on an unprecedented scale. They help each other through their networks, notable EUA with its Council for Doctoral Training (CDE) ${ }^{31}$ Smaller networks like Coimbra, LERU and UNICA are also active in this field. A communication strategy will be developed to promote the advantage of "doing your doctorate in Europe" and this should, in my view, become a prominent topic for the Bologna Ministerial Conference in May 2015 in Yerevan, Armenia.

\section{Concluding remarks}

Universities play a central role in the development of their country. They produce and process knowledge and transmit this knowledge to the next generation, to the economy and to society at large. Universities need to take action in order to become even more successful players at local, regional, national, European and international level. Actions include modernisation in education, research and innovation. Special attention should be given to human resources management and doctoral training. European initiatives can act as a catalyst. Some are emerging as 'European Public Goods' as is illustrated in this article, notably the European student loan guarantee facility, the European Research Council and the European Pension Fund for Researchers.

30 "Report of the ERA Steering Group Human Resources and Mobility (ERA SGHRM)," http://ec.europa.eu/euraxess/pdf/research_policies/SGHRM_IDTP_Report_Final.pdf.

${ }^{31}$ EUA Council for Doctoral Education (EUA-CDE), http://www .eua.be/cde/Home.aspx. 